\title{
ANALYSIS OF WATER EROSION PROCESSES USING TERRESTRIAL LASER SCANNING
}

\author{
Pawel DĄBEK ${ }^{1) *}$, Romuald ŻMUDA ${ }^{1)}$, Bartlomiej ĆMIELEWSKI ${ }^{2)}$ and Jakub SZCZEPAŃSKI ${ }^{3)}$ \\ ${ }^{1)}$ Institute of Environmental Development and Protection, Wroctaw University of Environmental and Life Science, \\ Pl. Grunwaldzki 24a, 50-363 WROCEAW \\ ${ }^{2)}$ Institute of Geodesy and Geoinformatics, Wrocław University of Environmental and Life Science, Ul. Grunwaldzka 53, 50-363 WROCŁAW \\ ${ }^{3)}$ Department of Spatial Economy, Wrocław University of Environmental and Life Science, Ul. Grunwaldzka 53, 50-363 WROCŁAW \\ *Corresponding author's e-mail: pawel.dabek@up.wroc.pl
}

\begin{tabular}{l} 
ARTICLE INFO \\
\hline Article history: \\
Received 6 February 2013 \\
Accepted 3 September 2013 \\
Available online 26 November 2013
\end{tabular}

Keywords:

\section{Monitoring}

Soil water erosion

Terrestrial laser scanning

Skid trail

Intensity of erosion

\begin{abstract}
The paper presents the preliminary results of the analyses of soil water erosion processes occurring in forestry mountain catchment area in the West Sudetes Mountains (Poland). The research was carried out within the area of skid trails, which were used until the end of 2010 in obtaining timber and its mechanical transport to the place of storage (logging). As a consequence of the forestry work the surface layer of soil on the wooded slopes was changed, which combined with the unfavourable hydro-meteorological conditions contributed to the intensification of water erosion processes.

Innovative in erosion analyses was using terrestrial laser scanning (TLS). It enabled the analyses of the dynamics of erosion processes both in time, and in spatial terms. The aim of the analyses was to identify areas of erosion and accumulation of the material, as well as to determine the intensity of the erosion processes and their quantitative examination. The research project focuses human impact on a forest ecosystem caused by the artificial delimitation of traffic routes and its influence on the natural balance of environmental conditions as well as contribution to significant intensification of soil erosion processes.
\end{abstract}

\section{INTRODUCTION}

Human influence on the natural balance of forest complexes by planning a network of forest roads and skid trails and timber harvesting, has a negative effect on the soil protective function performed by the forest. It also affects the retention capacities of these areas (Burley et al., 2004; Chang, 2003; Croke et al., 2001; Kusiak and Jaszczak, 2009; Luo and Zhou, 2006). The change of land use and topography (Akay et al., 2008; Burley et al., 2004; Prochal et al., 2005; Ramos Scharrón, 2010), and thus the strength of the ground, is the result of assigning the area to the transport and communication purposes. This leads to the intensification of soil erosion processes, resulting from runoff concentration on the surface of forest roads and skid trails (Akbarimehr and Naghdi, 2012).

Issues of runoff and water erosion on the surface of forest roads were summarised by Burroughs et al. (1989). Precipitation was simulated using sprinklers, then erosion volume was measured. Similar studies were carried out in Spain. Martínez-Zavala et al. (2008) used simulated precipitation on plots covered with vegetation and exposed that were localised on backslopes. By measuring the volume of the outflow and the amount of eroded material, he showed dependence of topography and vegetation cover on soil erosion intensity. Also Chang (2003) raised hydrological conditions influence on the issue of erosion processes in his elaboration about forest hydrology. He draws attention to the fact that the network of forest roads and trails is the basis of the forest management. However, as much as $90 \%$ of the debris originating from forest areas deposited in streams may have come from forest roads. Separation of pathways not only exposes the surface of the ground, making it vulnerable to erosion, but also subjects it to factors associated with the movement of vehicles. In areas of high relief erosion occurring on roads located on the slopes can generate 70 to $90 \%$ soil loss from roads network of entire area. Similar relations is also indicated in the work of Froehilch (1975, 1982), Prochal (1987), Katrycz (1998), and the work of the Froehlich and Słupik (1986).

Problems of water erosion in mountainous areas such as the Sudetes Mountains were studied by Pierzgalski et al. (2007), Jała and Cieślakiewicz (2004), Fatyga (1973) or Rojek and Żmuda (1992), however the focus was mainly on the intensity of water erosion by evaluating debris deposition in streams. Research carried out in forest catchments in the Polish Sudetes Mts. (Pierzgalski et al., 1998), (Kusiak et al., 2009) showed that linear erosion on the slopes have mostly been initialised by anthropogenic activities. The main factor contributing to the 
intensification of soil erosion in these areas is the incorrect location of roads and trails in relation to the terrain (local relief). Minimization of erosion processes occurring on forest roads is most dependent on their proper location within the terrain, proper drainage system and ongoing maintenance.

Forest road network is designed primarily for carrying out forestry work. Often this results in a dense network of the roads, because they are most often located perpendicularly or obliquely to the slope, that is in the line of maximum slope. When designing forest road system its impact on the hydrological-erosion conditions of forests mountain catchment is often ignored. In Poland legal aspects related to the design and construction of forest roads are described by Act of Building Law (1994), Act of Forests (1991) etc. The guide "Forest road" (Dzikowski et al., 2006) specifies in details technical conditions that should be taken into account while planning of roads and trails. Susceptibility to the impacts of erosion on forest roads and trails should be evaluated according to the classification of the consequences of erosion (Dzikowski et al., 2006). This classification refers to the dirt roads, i.e. the majority of forest roads. According to this classification four levels of erosion are identified: I - damage caused by flowing water is small and the usefulness of the road is constant, II - furrows about $5-10 \mathrm{~cm}$ deep, III - furrows about $30-40 \mathrm{~cm}$ deep, this condition reduces the roads usability, IV - the road is blurred, thus it is not suitable for further use. When designing the localisation of skid trails in mountainous areas, for the transport of timber, it is recommended that the location of roads on the land relief allows to avoid the level of erosion consequences is higher than II. If the effect of erosion is classified as the level III it is only recommended that skid trails are given the proper transverse slope and ensured proper drainage. At a slope more than 25 $\%$, resigning from mechanical and horse timber logging should be considered Dzikowski et al. (2006). Simultaneously, Kubiak (1998) mentions that the mountains skid trails should be localised exactly in the line of maximum slope. These guidelines are related to the minimization of damage in the forest stand and the technical capabilities of modern forest machines. They can even work on the $45 \%$ slopes, but only if they move exactly in the slope line. On the other hand, Pierzgalski et al. (1998) indicates the disadvantages of localisation skid trails obliquely to slope, especially at very long stretches, because these trails become open channels collecting runoff from the upper part of the slope. The paper suggests that while planning forest roads and skid trails networks hydrological and hydraulic aspects should be taken into account. Furthermore, Ciepielowski (1997) suggests that the reason for the lack of improvement in the prevention of soil erosion in forested areas is Forest Service's inadequate attention of the problem.
In the Polish Sudetes Mts. water erosion is one of the major processes degrading the environment. Taking regional conditions as a criterion, there have been identified four regions with different degrees of water erosion risk. Sudetes Mts. severely threatened by erosion are among the so-called mountain region (Nowocień, 2008). They are classified as an area within the fourth degree hazard (in 5-point scale) of potential water erosion, and as an area of average degradation if it comes to the accelerated water erosion (Wawer, 2002). Identifying areas under soil erosion occurrence and areas potentially threatened with intensification of erosion processes contributes to better soil protection (Jała and Cieślakiewicz, 2004). Therefore, the research project is legitimate as it aims at determining the hydrological and erosional conditions and the intensity of these phenomena in the context of forest roads and skid trails and the effect of anthropogenic activities carried out in a sustainable forest complexes.

Development of geodetic technology and measurement tools allows to use of geodetic methods for the measuring soil erosion and precise determination of its size, even in difficult local terrain conditions. It is important especially in the case of significant difficulties in carrying out measurements using traditional methods, such as runoff plots or measurement of soil loss volume. Such studies also offer the ability to track processes which transform the terrain in natural conditions without restrictions that exist e.g. on the research plots.

Terrestrial laser scanning technology was used to conduct field measurements. From a technical point of view laser scanning is a development and modernization of the methods used in geodesy (Vosselman and Maas, 2010). Touchless distance measurement using a laser beam, associated with precise angles measurement, allows to set the $\mathrm{XYZ}$ coordinates of the measured points and in the case of surface analyses - coordinates of each point of the resulting data cloud. The studies conducted so far have shown that in fact homogeneous procedures and techniques of test accuracy of scanner measurements have not been established (Kersten et al., 2008; Falkowski, 2007; Gordon et al., 2004). It may be concluded, that considering the geodetic warp error by using current laser scanners, it is possible to set the coordinates with a few millimeters accuracy. In summary, terrestrial laser scanning technology has changed the way of analysing the phenomena occurring in the surrounding reality: from geodetic measurements (measurement of discrete points) to the analyses carried out on the 3D models. The economic criteria should also be paid attention to: time, relative quick measurements (measuring a single session did not exceed two hours in the terrain), and finally entering the previously inaccessible areas of analysis.

The use of terrestrial laser scanning enabled to analyse the dynamics of erosion processes. The used research methodology allowed to analyse changes in 
both time and spatial terms. The research problem is only marginally described at the scientific community. Using TLS method enables its wider analysis with the benefit of such organisation like the State Forests. The main purpose of the studies was to recognised the intensify and volume of soil erosion at forest trail in mountain region innovatively using TLS method.

\section{METHODS}

Terrestrial laser scanning technology was used as an innovative implementation of modern surveying technology during the research into the changes of the local relief resulting from water erosion of soil. Traditional surveying methods (Prochal, 1987; Prochal et al., 2005) were based on the use of leveling in the analysis of changes of ground elevation as a result of erosion, or debris accumulation in reservoir. The use of traditional geodetic tools, such as leveling, allows only to spot metering of the changes in the land relief and usually it demands to average the results. With the TLC methodology the analysis for a larger area is possible, but it involves a significant investment of time and high risk of errors. Terrestrial laser scanning allows to examine the reshaping of the terrain for the entire experimental area taking into account changing terrain structure of both the vertical axis (depth rills), the horizontal axis (width and length of rills), as well as the spatial arrangement. It also enabled the investigation of the formed rills network.
Moreover, it allows to determine concentrated runoff routes.

Field research employing terrestrial laser scanning took place on the experimental area located at the Przedgórze Izerskie (Western Sudetes Mts.). The research were conducted in 2011: in June and September, to register the intensity of the erosion processes.

Leica ScanStation 2 was used in the measurements. It was considered that the impulse scanner of measuring speed 50,000 points $/ \mathrm{sec}$ and range up to $300 \mathrm{~m}$ (90\% albedo) would be a sufficient tool for surface measurements. Laser technology allowed to obtain measurable and fully objective points models of the terrain in a short time. Established and executed a scanning resolution was $5 \times 5 \mathrm{~mm}$ at a distance of $10 \mathrm{~m}$. Accuracy scans connection for a single measurement campaign, did not exceed $\pm 3 \mathrm{~mm}$. The accuracy obtained for all measurement campaigns (each carefully reconstructed position of disk representing warp) did not exceed $\pm 1.5 \mathrm{~cm}$. The average density of the points cloud in respective sectors skid trail is shown in Figure 1.

Terrestrial laser scanning method provided a semi-product in the form of points cloud covering the surface of the research object. The obtained scan (coordinates in the scanner local coordinate system as a text file) were imported to the TerraScan (Microstation environment), where the data were pre-

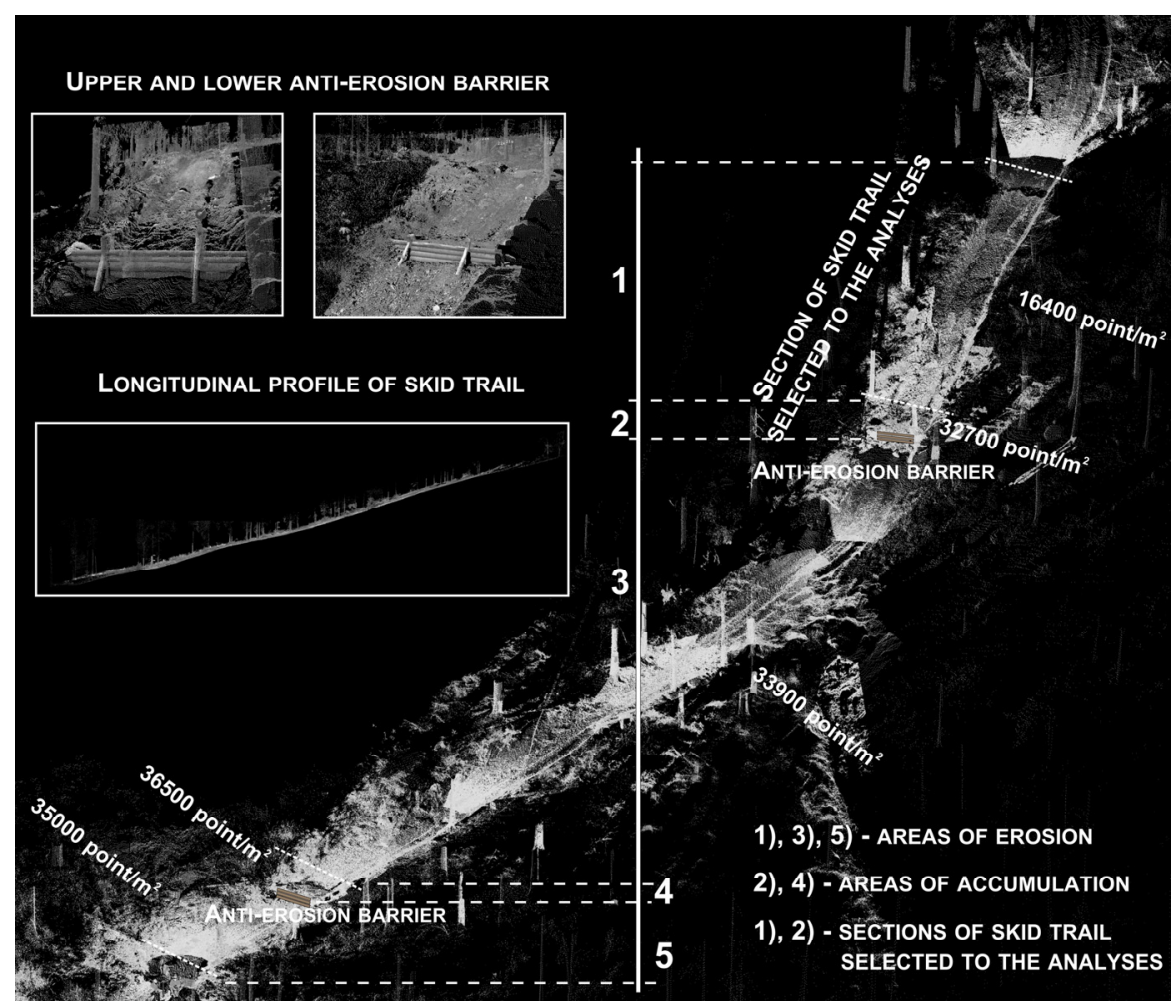

Fig. 1 Study area of skid trail in Szklarska Poręba Forestry District, location of anti-erosion barriers, division and average density of the points cloud from TLS in respective sections. 
filtered. For this purpose the defined data classification algorithm - Ground Routine was used, as it classifies ground points by iteratively building a triangulated surface model. The routine starts by selecting some local low points that are confident hits on the ground. Then an initial model was built from the selected low points. Triangles in this initial model were mostly below the ground with only the vertices touching ground. Each added point makes the model following the ground surface more closely. Interaction parameters determine how close a point must be to a triangle plan for being accepted as ground point and added to the model (Soininen, 2012). The prepared data were imported to Surfer10, where the data interpolation and the main analyses took place. Interpolations were made by kriging and by triangulation with linear interpolation (Galon, 2011), creating a grid with a spacing of $1 \times 1 \mathrm{~cm}$. Comparative juxtaposition of the terrain models obtained by the two methods of interpolation showed an error of \pm 1 $\mathrm{cm}$, which in the surface analyses are a fully satisfactory result.

The outcome of measurements using terrestrial laser scanning and compilation of the results showed where soil erosion occurred and where the material was accumulated. Analyses of 3D models created from laser scanning also allowed to establish precisely intensity of the ongoing erosion process.

\section{GENERAL DESCRIPTION OF THE STUDY AREA}

The research area is located in the western part of the Sudetes Mountains, the band of Jizera Mountains on the slope of Ciemniak Mountain (GPS coordinates of the research object N: $52^{\circ} 10$ '26 ", E $\left.18^{\circ} 51^{\prime} 9^{\prime \prime}\right)$. Area of research is the area of forest which is managed by Szklarska Poreba Forest District (Regional Directorate of State Forests in Wroclaw, The State Forests National Forest Holding).

Szklarska Poreba Forest District is located in the southern part of Lower Silesia. Its area is about 14,200 hectares, and forest cover stands at around $58 \%$. The forests of this area are characterised by primarily artificially introduced forest stands (mainly spruce) on surfaces that had been significantly transformed over the years as a result of anthropogenic activities (Prochal, 1987). Western Sudetes Mts. is the area, where resulting from the ecological disaster (1977-1985), large-scale destruction of mountain forest stands can be encountered. Moreover, the stands have not been fully rebuilt yet. The environmental disaster in the Sudetes Mts. left its mark in the structure of the soils profiles that were degraded as a result of intensive erosion processes. In consequence retention capacity of the soil and thus the entire area was reduced (Pierzgalski et al., 2007). Forest Districts' area is mountainous, only the northeast is an upland. It is a highly variable relief area, with steep slopes and different aspect of the slopes. Because of topographic and climatic characteristics handling the forest management in this area is challenging. Decisions on the location of forest roads and skid trails infrastructure have to be responsibly and properly planned.

To achieve the objectives of the research project the forest experimental area was selected. It was the place where in 2010 sanitation harvest and timber harvesting were conducted. For proper and efficient organisation of timber logging a skid trails network had been planned. It was used to transport logs from the harvesting to the storage place. Skid trails are located in accordance with the internal regulations of The State Forests National Forest Holding and the principles of environment protection (Dzikowski et al., 2006), including in particular the protection of existing forest stands from damage. In the areas of heavy relief and significant slopes, the used trails cause degradation of surface layer of soil, changes in local relief, and thus favour the intensification of the processes of soil erosion. Figure 2 presents changes in the local relief of the skid trail which occurred in the year following the completion of forestry work in the area.

The entire length of the skid trail running almost from the top of Ciemniak Mt. to the road located across to slope in the lower part of the slope, was selected for analyses. Section of about $150 \mathrm{~m}$, which is characterised by an average slope of about $20 \%$, and locally even more than $35 \%$ was chosen. The trail is located mostly in the line of steepest slope. In the experimental area, on the trail, two anti-erosion barriers of approximately $0.5 \mathrm{~m}$ height made of poles were mounted horizontally. The exact location of barriers and sizes of each sector of the experimental area are shown in Figure. 1.

For the presentation of the results, the upper part of the analysed skid trail which ends with anti-erosion barrier was selected. Area of the selected section is about $40 \mathrm{~m}^{2}$, with an average width of about $2 \mathrm{~m}$ and length of about $17 \mathrm{~m}$. This section of the trail has an average longitudinal slope of about $35 \%$. The density of points cloud from terrestrial laser scanning of the selected section of the trail is above 16,000 points per $\mathrm{m}^{2}$, and for the area directly in front of the installed barrier it is over 32,000 points per $\mathrm{m}^{2}$ (Figure. 1). This accuracy allowed to build DTM of analysed area, and then conduct the analysis and interpretation of results.

Before proceeding to the main analyses of data obtained from terrestrial laser scanning, the entire area was analysed in terms of local terrain conditions. Airborne laser scanning (ALS) was made in the Forest District in 2007. Basing on digital terrain model (DTM) with a resolution of $0.2 \mathrm{~m}$ created from the ALS, the analysis of the distribution of runoff concentration vectors was conducted. The analyses were performed using ArcGIS 9.3. The results proved that examined skid trail area, due to the original topography is not an area where there is a concentration of runoff. Healthy forest litter absorbing precipitation properly is situated in adjacent areas. 

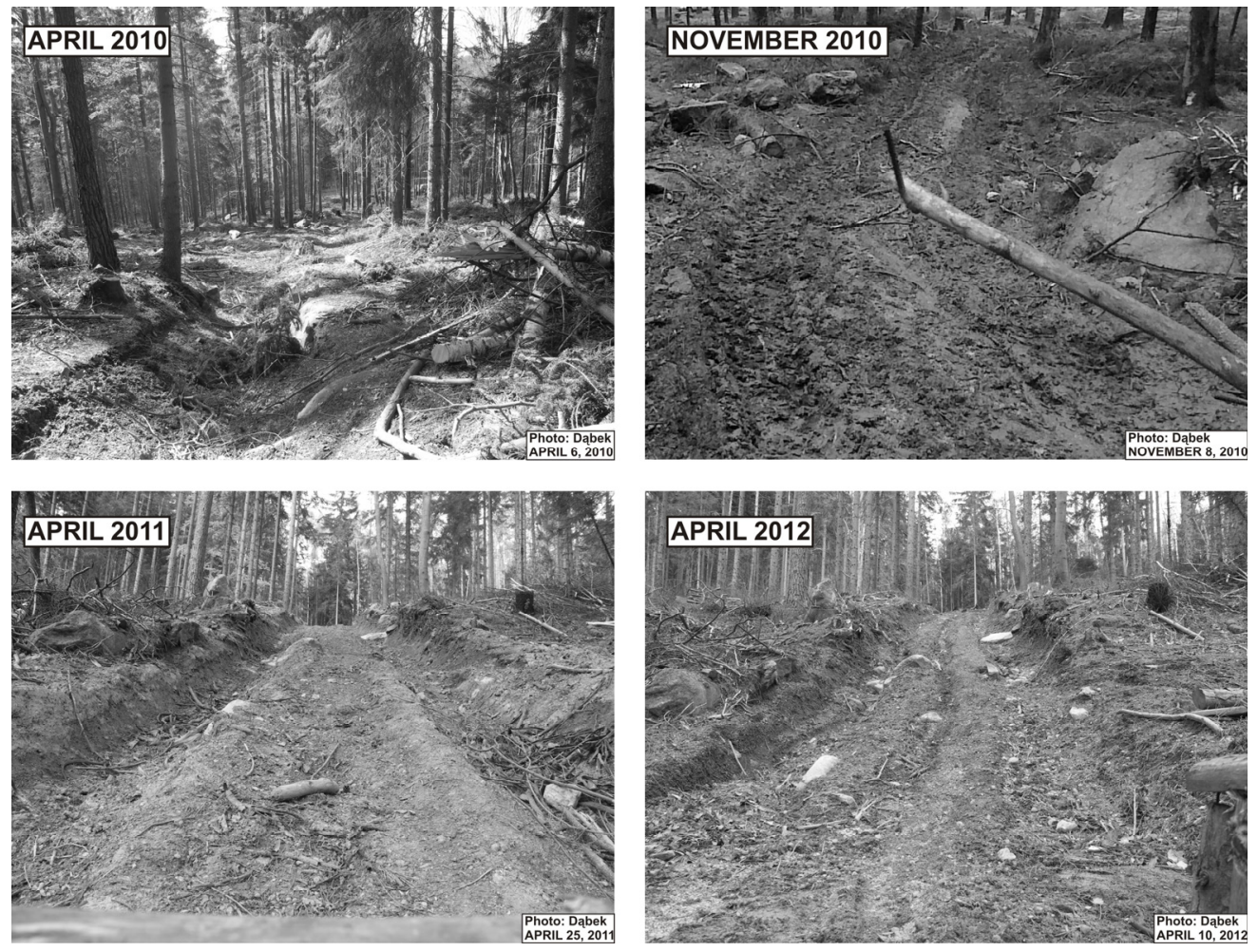

Fig. 2 The local relief of the skid trail area in 2010-2012 - photographic documentation.

Conducted field observations, including heavy rainfall time, proved that there is no influx of the water from adjacent areas into the trail surface. Erosion processes that occur there are therefore the result of the runoff concentration only from the surface of the trail.

\section{RESULTS AND DISCUSSION}

Comparing the effects of each scanning model of the skid trail surface led to the evaluation of changes in local relief. The results of modeling basis of the analysis of scans carried out in June and September of 2011 are shown in Figure 3. They present the changes of erosion caused during this period. Changes that occurred on the land relief allow to conclude that on more than $30 \%$ of selected section of skid trail erosion processes occurred. On the line of runoff concentration, that took place in the ruts created due to the movement of heavy forestry tractors and dragging timber, rills of 1 to $10 \mathrm{~cm}$ deep were formed. The analysis of the models also showed intense erosion occurring of embankment trails. Dimensions of the rills and their location along the skid trail suggested that the intensity of erosion had depended on local relief of trail surface, local slopes and stability of the ground. The estimated volume of the eroded material during the period, from the analysed area was more than $1.2 \mathrm{~m}^{3}$. This value is calculated as the volume of all the rills formed on the section of the trail. The exact distribution of terrain changes is presented in Figure 3. The eroded material was accumulated at the bottom of the section of the trail at the installed anti-erosion barrier. Accumulation volume was estimated to be about $0.9 \mathrm{~m}^{3}$. Analysis of 3D terrain model and soils transport routes showed that some of the debris, about $0.3 \mathrm{~m}^{3}$ was transported over the barrier with runoff. Distribution of thickness of accumulated material is presented in Figure 3.

Interpolation of points cloud (obtained from the scanning) at a spacing at $1 \times 1 \mathrm{~cm}$ allowed accurate analysis of the rills, even of minimum depth, caused by erosion. Interpolation of data from a lower resolution, or the adoption of traditional surveying methods, would not show so well the changes of the local relief that had taken place on the research area. As a result of inaccurate interpolation or measurement errors, the volume of denudation processes that occurred in the environment may be too under- or over-averaged.

In the forest the most eroded are roads along and obliquely to slope, where the intensity of runoff is highest. This phenomenon can be compared to the intensity of the processes taking place on dirt road of agricultural areas (Szewrański and Żmuda, 2008; Żmuda, 2006). With regard to those conditions, soil protection in forest areas would be reduced by proper designing and protecting forest roads and trails (Wawer, 2002; Wawer et al., 2008). A similar phenomenon also analysed Croke et al. (2001). He proved that the soil loss from the surface of skid trails is about 30 -fold higher than from the surface on which 


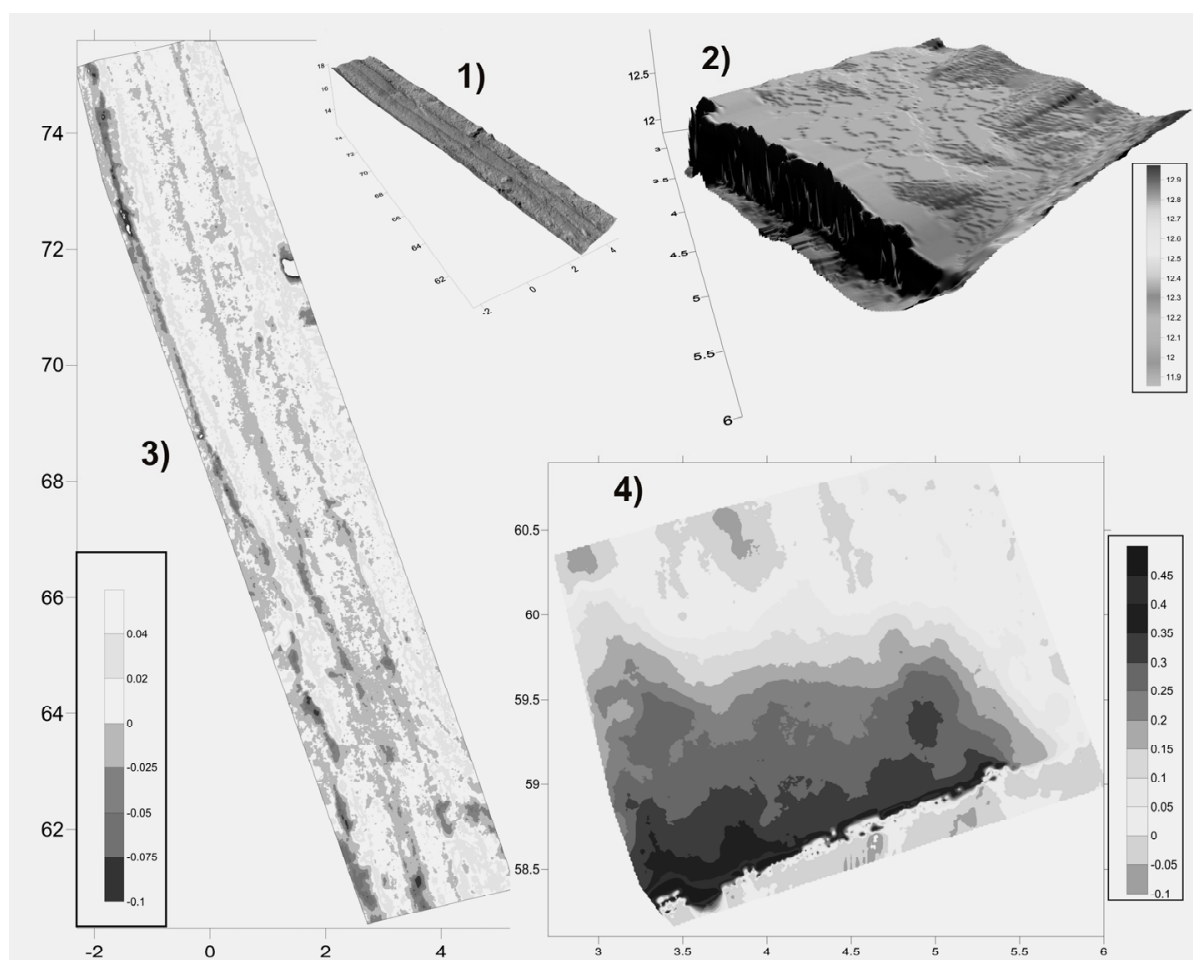

Fig. 3 Results of modeling:

1) 3D model of erosion area with rills formed in period june-september 2010;

2) 3D model of accumulation area on anti-erosion barrier;

3) distribution of depth of rills formed on study area;

4) distribution of thickness of erosion material on accumulation area in front of anti-erosion barrier.

the timber was harvesting. The differences are particularly evident up to 1-2 years after the implementation of forestry work. During the research period erosion processes in the areas adjacent to the trail where timber harvesting was conducted were not observed. The erosion processes occurred only on the area of skid trail.

Also Chang (2003) showed that the roads and trails located on steep slopes, areas of unstable ground or where there are heavy rains, have potential in the production of debris. The developed linear system of breached soil structure, as in Chang (2003), are places of runoff concentration arising during torrential and heavy rain. Appropriately unsecured skid trails in unfavourable hydro-meteorological conditions pose a threat to the area located below i.e. rapid runoff from the catchment, lack of retention, flood risk or transport debris.

The adopted methodology made it possible to evaluate quickly the intensity of erosion processes and the volume of transported material. Field measurements compared to traditional methods are relatively quick and easy to perform, and do not require large financial outlay. However, It is important to maintain regular warp points. Methodological solutions adopted in the research have yet another important advantage - it is possible to identify the exact areas where erosion processes are more intense, and where it is potentially possible to use devices to reduce debris transport.

\section{CONCLUSIONS AND FUTURE WORK}

The study represents an innovative approach to the subject that is rarely undertaken in environmental research. Research methodology adopted for the evaluation of linear erosion processes using terrestrial laser scanning represents the use of modern surveying methods that takes into account technology advances in that field. Simultaneously, the analytical process allows to determine precisely the changes that occur on the mechanised forestry work skid trails. These are the places of runoff concentrations that are anthropogenically created for the purpose of economic activity. The transformation of the forest environment, would significantly reduce the scope of the protective functions of forest contributing to the intensification of soil erosion processes.

The research results presented show high analytical capabilities of the employed TLS method. It was applied to forest areas, which are generally regarded as the best biological protection of soil, increasing retention of soil and reducing deposition of debris in the streams. Undertaken study shows that 
inadequately located skid trails and leaving them unsecured after the forestry work results in intensive erosional processes even in a short period of time.

Research has shown that in a relatively short time (3-month observation period) within an area of about $40 \mathrm{~m}^{2}$ due to the water erosion the soil loss was approximately $1.2 \mathrm{~m}^{2}$. Moreover, it was proved that the anti-erosion barrier fulfilled their function, through an effective accumulation of transported erosion material. The TLS method that we used in research allowed us to analysed formed rills as a result of erosion. Traditional methods of analysis erosion do not give the opportunity to analyse the layout and dimensions of the erosion effects. Only a quantitative measurement of the effect is possible.

The project and undertaken research problem is significant for the development of scientific disciplines such as forestry, forest hydrology, water reclamation and remote sensing. The use of TLS, modern measuring apparatus and innovative approach, it becomes easier to ensure the safety of fluvial systems in the Sudetes Mountains. Exploring the topic is more justified in the light of ongoing research in the areas of the Polish mountains and adds to the programs aimed at increasing small scale retention in forest areas.

\section{ACKNOWLEDGEMENT}

The research presented in the paper were partially funded by The Office of the Marshal of the Lower Silesia Voivodeship, Department of Economics, of funds for 2012-2015 as part of the project "GRANT PLUS" (Human Capital Programme, Priority VIII Regional Economy Personnel, Activity 8.2 Transfer of Knowledge, Subactivity 8.2.2 Regional Innovation Strategies) under contract number DG-G/3272/12. The research is supported by the cooperation agreement signed by the Institute of Environmental Protection and Development at Wroclaw University of Environmental and Life Sciences and Forest District Szklarska Poreba.

\section{REFERENCES}

Act of Building Law of 7.7.1994, Dz.U. 1994 nr 89 poz. 414 (tekst jednolity z dnia 1.11.2010 r. - Dz.U. $2010 \mathrm{nr}$ 243 poz. 1623) (in Polish: Ustawa Prawo budowlane).

Act of Forests of 28.9.1991, Dz.U. 1991 nr 101 poz. 444 (tekst jednolity z dnia 13.12 .2010 r. - Dz.U. $2011 \mathrm{nr}$ 12 poz. 59) (in Polish: Ustawa o Lasach).

Akay, A.E., Erdas, O., Reis, M. and Yuksel, A.: 2008, Estimating sediment yield from a forest road network by using a sediment prediction model and GIS techniques, Building and Environment, 43, 687-695.

Akbarimehr, M. and Naghdi, R.: 2012, Determination of most appropriate distance between water diversions on skid trails in the mountainous forest, north of Iran, Catena, 88, 68-72. DOI: 10.1016/j.catena.2011.08.005

Burley, J. (Eds.), Evans, J. and Youngquist, J.A.: 2004, Encyclopedia of forest sciences, $2061 \mathrm{pp}$.

Burroughs, E. R. Jr. and King, J. G.: 1989, Reduction of soil erosion on forest roads, General Technical Report
INT-264, United States Department of Agriculture, Forest Service, Intermountain Research Station, $24 \mathrm{pp}$.

Chang, M.: 2003, Forest hydrology: An introduction to water and forests, ISBN 0-8493-1363-5, CRC Press LLC, USA, 373 pp.

Ciepielowski, A.: 1997, Questionnaire about diagnosis of erosion in the forest on a scale of Forestry District In: Constant observations of hydrological and erosion processes in the Sudety Mountains (in Polish), IBL, Warszawa.

Croke, J., Hairsine P. and Fogarty, P.: 2001, Soil recovery from track construction and harvesting changes in surface infiltration, erosion and delivery rates with time, Forest Ecology and Management, 143, 3-12. DOI: 10.1016/S0378-1127(00)00500-4

Dzikowski, J., Szarłowicz, A., Burzyński, S., Rajsman, M., Satoła, J. and Wiązowski, Z.: 2006, Forest roads. Technical guide (in Polish), Warszawa-Bedoń, $136 \mathrm{pp}$.

Falkowski, P.: 2007, Experiences related to utilisation of laser scanning for engineering surveying tasks (verification of accuracy capabilities), Reports on Geodesy, no. 1/82, 61-67.

Fatyga, J.: 1973, The occurrence and severity of water erosion of soil in the region of the Sudety Mountains in years 1965-1970 (in Polish), manuscript, Wrocław.

Froehlich, W.: 1975, The dynamics of fluvial transport of Kamienica Nawojowska (in Polish), PAN, Pr. Geogr. no. 114, Zakł. im. Ossolińskich, Wrocław-WarszawaKraków-Gdańsk.

Froehlich, W.: 1982, The dynamics of fluvial transport of Kamienica Nawojowska (in Polish), Prace Geogr. IGiPZ PAN, no. 143, 144 pp.

Froehlich, W. and Stupik, J.: 1986, The role of roads in the formation of runoff and erosion in the Carpathian flysch basins (in Polish), Przegl. Geogr, no. 58, 1-2, 67-87.

Galon, Z.: 2011, Surfer ${ }^{\circledR} 10$ User Guide (in Polish), Kraków, $490 \mathrm{pp}$.

Gordon, S.J., Lichti, D.D., Stewart, M.P. and Franke, J.: 2004, Modelling point clouds for precise structural deformation measurement. Proceedings ISPRS Conference Commission V, Istanbul, 1014-1019.

Jała, Z. and Cieślakiewicz, D.: 2004, Potential erosion of soil erosion in the Karkonosze National Park In: Geoekologicke problemy Krkonoš. Mez. Věd. Konf. November 2003 (in Polish), Szklarska Poręba. Opera Corcontica, no. 41, 66-73.

Jordán, A. and Martínez-Zavala, L.: 2008, Soil loss and runoff rates on unpaved forest roads in southern Spain after simulated rainfall, Forest Ecology and Management, 255, 913-919. DOI: $10.1016 /$ j.foreco.2007.10.002

Katrycz, M.: 1998, Sediment transport in the basin of Wilczy Potok - Eastern Karkonosze Mts. (in Polish), Acta Univ. Wratisl., no. 2061, Prace Instytutu Geograficznego, series A, Geografia Fizyczna, 9, 3758.

Kersten, Th., Mechelke, K., Lindstaedt, M., and Sternberg, H.: 2008, Geometric accuracy investigations of the latest Terrestrial Laser Scanning Systems, FIG Working Week Stockholm, 1-16.

Kubiak, M.: 1998, Forest transportation (in Polish), The August Cieszkowski Agricultural University of Poznań, Poznań, 343 pp.

Kusiak, W. and Jaszczak, R.: 2009, Propedeutics of forestry (in Polish), Wyd. Uniwersytety Przyrodniczego w Poznaniu, Poznań, 143 pp. 
Luo, Y. and Zhou, X.: 2006, Soil Respiration and the Environment, Elsevier, Inc., 316 pp.

Martínez-Zavala, L., Jordán López, A. and Bellinfante, N.: 2008 , Seasonal variability of runoff and soil loss on forest road backslopes under simulated rainfall, Catena, 74, 73-79. DOI: 10.1016/j.catena.2008.03.15

Nowocień, E.: 2008, Selected problems of soil erosion in Poland (in Polish), Studia i Raporty IUNG - PIB, no. 10, 9-38.

Pierzgalski, E., Kucharska, K., Tyszka, J., Stolarek, A., Boczoń, A., Fortuński, M. and Wiślińska, B.: 1998, Constant observations of hydrological and erosion processes in forest mountain areas (in Polish), IBL, Warszawa, $75 \mathrm{pp}$.

Pierzgalski, E., Janek, M., Kucharska, K., Tyszka, J. and Wróbel, M.: 2007, Hydrological study of forest catchments in the Sudetes Mountain (in Polish), IBL, Sękocin, 84 pp.

Prochal, P. (Eds.): 1987, Fundamentals of agricultural melioration (in Polish), PWRiL, Warszawa, 2, $419 \mathrm{pp}$.

Prochal, P., Maślanka, K. and Koreleski, K.: 2005, Protection of the environment against water erosion (in Polish), Kraków, 126 pp.

Ramos Scharrón, C.E.: 2010, Sediment production from unpaved roads in a sub-tropical dry setting Southwestern Puerto Rico, Catena, 82, 146-158. DOI: $10.1016 /$ j.catena.2010.06.001

Rojek, W. and Żmuda, R.: 1992, Intensity of water erosion in the catchment of streams "Jarków" i "Ptasznica" in Eastern Sutedes Mts. (in Polish), Zesz. Nauk. AR Wrocław, no. 214, Rolnictwo LVI, 33-40.

Soininen, A.: 2012, TerraScan User's Guide, Terrasolid, $311 \mathrm{pp}$.
Szewrański, Sz. and Żmuda, R. (Eds.): 2008, Forecasting the environmental effects caused by the implementation of principles of good agricultural practices (in Polish), Wyd. Uniwersytetu Przyrodniczego we Wrocławiu, $85 \mathrm{pp}$.

Vosselman, G. and Maas, H.G.: 2010, Airborne and Terrestrial Laser Scanning, Boca Raton, CRC.

Wawer, R.: 2002, Vademecum of erosion and agricultural sciences (in Polish),

http://www.erozja.iung.pulawy.pl/VademecumPl.htm, 10.03.2012 r.

Wawer, R., Nowocień, E., Podolski, B., Szewrański, Sz. and Żmuda, R.: 2008, Analysis of the agricultural road network in terms of protection against surface water erosion (in Polish), Zesz. Probl. Post. Nauk Roln. No. 526, 257-263.

Żmuda, R.: 2006, Fluvial transport system functioning in small catchment threatened by soil water erosion (in Polish), Zesz. AR we Wrocławiu, Rozprawy CCXLIII, 544 pp. 